\title{
Exotica Pagatan Weaving as A Learning Source in Establishing Values and Local Wisdom
}

\author{
Yudha Adrian \\ STKIP PGRI Banjarmasin, South Kalimantan, Indonesia \\ androiid337@gmail.com
}

\author{
Sa'adah Erliani \\ STKIP PGRI Banjarmasin, South Kalimantan, Indonesia \\ saadah.erliani@gmail.com
}

\author{
Rahidatul Laila Agustina \\ STKIP PGRI Banjarmasin, South Kalimantan, Indonesia \\ rahidatul.laila@yahoo.com
}

\begin{abstract}
This study aims to describe the exotica of Pagatan weaving as a learning source in establishing values and local wisdom in Tenun Pertiwi Pagatan Village, Kusah Hilir District, Tanah Bumbu Regency, South Kalimantan. The method used in this study is descriptive qualitative. Data collection techniques used were observation techniques, recording, interviews and record techniques. Weaving Pagatan as a source of economic development is very profitable as a source of income, a culture that needs to be passed down from generation to generation and social characteristic of Bugis Pagatan people. In this framework of local wisdom, inter-individual, inter-community groups complement each other, unite and interact with existing norms and social norms. Local wisdom is identity. Local Information System, it compares the society with other local communities.
\end{abstract}

Keywords: exotica of Pagatan weaving, learning source, establish values and local wisdom

\section{INTRODUCTION}

Great nation is a nation that has strong characters derived from the values excavated from the society's culture. The values of local wisdom are not a hindrance to progress in the global era, but are a tremendous transformational force in improving the quality of human resources as the capital of a nation's competitive and comparative advantage. Therefore, extracting the values of local wisdom is a strategic step in the effort to establish the nation's character. Exotica of Pagatan weaving has a unique charm because it has not been widely known, so it is worth to be re-studied as a source of learning in establishing values and local wisdom.

Indonesia itself is known as a nation with rich tradition in traditional weaving cloth. According to Kamon (1983) in his book entitled Over 1,000 Patterns of Traditional Stripes and Lattices Design Collection stated that the weaving cloth with striped motive has been imported from Indonesia regularly to a number of countries started from the year of 1573. Increasingly, the type and pattern of the cloth kept growing and at least besides enriching the cloth fabric in Indonesia, it also proves that the Indonesian nation is open to other cultures. Unfortunately, many of these traditional fabrics are in danger of extinction. In addition to the many that are not produced anymore, it is also due to people less interested in preserving the culture of weaving and embroiding traditional cloth.

One important effort done to preserve the nation's culture is to preserve the weaving of the archipelago which is a reflection of the identity of the Indonesian nation is rich in the results of its weaving. It is no doubt that the Pagatan woven fabric becomes Indonesia's original local cultural product threatened with extinction, as the newspaper media preach. The woven fabric typical community Pagatan Bugis tribe, sub-district Kusan Hilir Tanah Bumbu Regency is a cultural heritage that must be preserved to each generation. On other hand, Pagatan weaving has been existence along with the presence of Bugis in Kusan Hilir sub district, Tanah Bumbu (Budhi, 2015).

Pagatan weaving is one of the works of Pagatan Women in Tanah Bumbu which is still produced using manual power. There are not many people who produce this weaving so that not many people know it. This is reasonable because in there is another traditional fabric in South Kalimantan called Sasirangan, as an iconic South Kalimantan fabric. Given weaving has historical values, meaning, high technique in terms of color, motive, and type of material or yarn used that has uniqueness between regions as well as character values. Not many young people are interested in this weaving activity because it requires patience and sincerity and high intentions to preserve one of these Bugis cultures. All of these play a role to maintain the production techniques, designs, and products produced so that the existence of Pagatan weaving can be known to many people, especially Indonesia.

Woven fabric has an exotic value namely the value of uniqueness or characteristic that has not been known by many people. As it is mentioned previously, besides Pagatan weaving, South Kalimantan actually has a very famous fabric and there are many people who have worn it in various formal and non formal events. As the efforts to preserve Pagatan's unique woven fabric, the community must inherit this skill to their offspring. Nowadays, the existence of Pagatan woven fabric is well known to people throughout the South Kalimantan, even to other countries. This becomes our "homework" together so that the fabric of this local culture is not "dormant" anymore. Society and government are altogether preserve the tradition of making this woven fabric more vigorous and more incessant for local cultural icons that are not found in the other areas so that it remains sustainable.

Based on the above explanation it has been explained that the inheritance of woven Pagatan is done through non formal education. Cultural 
inheritance of weaving is not structurally inherited to the children and grandchildren of the weavers. This will indirectly affect the inequalities of skills possessed by children and grandchildren. For children and grandchildren who are diligent in weaving it will be able to preserve the woven culture of the pagatan. things are different if the grandchildren and the weaver's child is not active in learning to weave it will cause a bad impact for the culture of weaving itself. It is not impossible that weaving culture will become extinct from Pagatan earth itself.

Ideally Pagatan weaving learned in formal education. From elementary level to high school level. Pagatan weaving learning will have a positive impact on Pagatan's own cultural continuity. Culture will be sustainable whether passed on to children and grandchildren through a long and unacceptable process instantaneously.

In the government regulation (PP) No. 19 of 2005 , states that local-based education as referred to in paragraph (1) is part of the education of religious and noble subjects, civic and personality subjects, science and technology subjects, group education aesthetic subjects, or a group of physical, sports, and health education subjects. Based on PP 19 this explicitly stated that the content poured in formal education should be inserted from the superiority of local wisdom in certain areas. In this case the local wisdom that is discussed is Pagatan weaving. Thus, the government has emphasized that educational content will be more meaningful if it is incorporated from local content areas tailored to the basic competencies set by the government and adapted to the relevant subjects.

To find out the benefits of Pagatan weaving as one of the learning resources is relevant to the subjects and basic competencies that have been established by the government. It is necessary to observe in depth in order to analyze what can be empowered into relevant learning resources in accordance with the government's reference. In addition, based on researcher observations is done on the weaving process of Pagatan woven that fabric can be used as a source of learning about how the characters or values contained in the process so that can be empowered into a source of learning on character education. Character education will be more meaningful when associated with the condition around the learner so that will bring awareness about the importance of character education in the environment of learners. Because environmental conditions is one of the factors that affect the nature, character, and behavior of humans who inhabit it (Herimanto and Winarto, 2010).

Based on the above explanation, it is necessary to observe in a structured and systematic way through a scientific approach. This is done to get the accuracy of the data obtained. This observation is done through qualitative study with the object of weavers study, the setting of fabric weaving and the surrounding community. The objectives of study are: (1) describing Pagatan weaving as a learning resources is from the local wisdom of South Kalimantan; and (2) describing good values that are integrated in Pagatan weaving production.

\section{METHODS}

This study employes qualitative approach in descriptive method. The reason for choosing this type of study is because, the study subject is natural (natural, study data in the form of words, sentences, paragraphs, actions or activities in Pagatan weavers environment.In line with the opinion Manjta (2008) states that qualitative study is a procedure study that produces descriptive data in the form of writing about the person or words and behavior of people. The data sources of this study are Pagatan weavers, residents around the weavers, and the environment around weavers live in the Pagatan district. Data collection techniques used in the form of purposive sampling.

Data collection in this study technique: (1) interview; (2) observation; and (3) documentation. This technique has been adapted the opinion of Creswell (2005) that the collection of qualitative study data using interviews, observation, and documentation. Based on the formulation of study objectives, data analysis is during and after data collection, with theme analysis techniques. The steps of qualitative data analysis as follow: (1) organizing interview data and observation data in the field; (2) presenting the interview data to determine the relevance of the theme of the problem in this study; and (3) presenting the field observation data to find out how the relationship between the theme of the problem in this study is associated with the data obtained from the interview results.

\section{RESULT AND DISCUSSION}

Based on the results of study conducted in the village Tenun Pertiwi Pagatan Village District Kusah Hilir Tanah Bumbu District South Kalimantan. It is found that Pagatan weaving is traditionally made traditional fabrics. Making this cloth is done for generations to remain sustainable in the regional and even national arena.

The making of woven pagatan has become a habit for Pagatan community itself. The crystallization of fabric weave becomes a unique culture for the community of the field. Thus, weaving Pagatan can be said as a culture that emerged from the work of the surrounding community derived from the taste and creation of society (Soemardjan and Soemardi, 1964).

Culture includes behaviors and belief systems that characterize old social groups (Ormrod, 2008). The presence of Pagatan weaving culture typical of Bugis tribe is certainly not separated from the history of the Bugis tribe who moved from South Sulawesi to Pagatan Kusan Hilir district Tanah Bumbu Regency. Although they have moved on, they continue to live their daily lives as well as in the culture of weaving for women because when they moved they did not forget to bring the looms. It is no wonder that the equipment, workmanship and decorative motives are the same, although they have left their hometown for a very long time.

Along with the development era, Bugis Pagatan fabric cannot compete with the factory products fabric. However, this weaving exotica that has not been 
widely known at that time still can survive even though it was almost deserted enthusiasts. Fortunately, there are still certain circles who appreciate this artwork, both for their own use and as souvenirs.

Currently, the development of Pagatan weaving has developed rapidly. Different types of clothing appear using this type of weaving. Pagatan weaving is not only used as traditional clothing only, but also various other types of clothing. Some of the leading designers in Jakarta, today began to glance to use woven fabric as a basic material to make a dress.

Other efforts are also made through training programs provided to adolescents to be trained to process Pagatan woven fabrics. In addition, he is also incessant in promoting this unique Pagatan woven fabric out of the area through the exhibition event and the uniform implementation of the day work for civil servants by using this woven cloth. It is also done through the cooperative Tenun Pertiwi which is always ready to provide Pagatan woven fabric based on the consumers demand.

Types of Pagatan woven fabric are as follows: (1) songket (sobbe), which consists of Sobbe Are and Sobbe Sumelang; (2) Ikat Weaving, it is made by tying yarn before it is dipped into the dye ( $m a$ 'bebbe); (3) Panji, this is different from both types of above with the motive of woven directly; (4) through the thread of feed or pasulu which is plaited on the dirian thread; and (5) Plain plaid sarong, which is the basis for an ornament. On further development, the types of woven plaid sarong are combined with various decorative motives. The basic shape of the boxes can be combined with songket, both sobbe are and sobbe sumelang. The basic form using woven checkered panji type or bebbe types.

In general, the actual Pagatan Weaving has a basic pattern (sujubila) which later became the basis of diverse patterns of decoration. The basic decoration patterns were made as reference to other particular fabrics for reference in their weaving. Some basic decoration patterns of Weaving Pagatan are for example the shape of birds, horses, tree kris at the sea (fujengki), arrows, birds on trees, geese, pigs, common trees, chain, lions, play darts, dragon, rabbits, flower vases, calligraphy, lilies, and other various motives.

\section{Functions of Pagatan Weaving}

At first Pagatan weaving is only the clothes of the kings, especially for the King of Bugis Pagatan fabric usually uses special motives. The work clothing is in the form of pants called "Sulara Pajama" shirt and sarong. Meanwhile, the sarong is only used by men. Usually this cloth is used during important events such as during the ceremony and on Idul Fitri and Idhul Adha. The development of Pagatan weaving functions continues to the present day as shown in Figure 1. Pagatan weaving has been widely used for various types of clothing according to the customers' desire. Some types of clothing made from Pagatan Weaving are such as sarong, tie, stagen, scarf, ordinary clothes, skirt, long cloth, Islamic dress, dance clothes, et cetera.

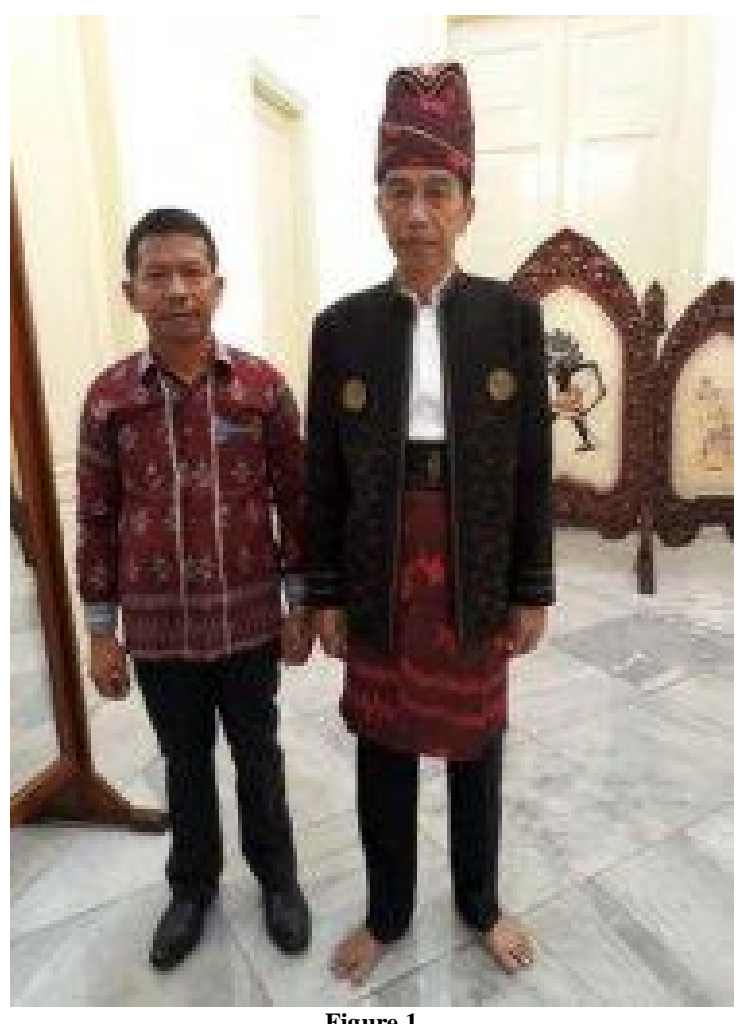

Figure 1

Jokowi dress up Pagatan Weaving on the Independent Day RI $\mathbf{7 2}^{\text {nd }}$ in Istana Negara Source: http://banjarmasin.tribunnews.com 


\section{Pagatan Weaving as a Learning Resource and Local Wisdom}

According to Brunner in Iskandarwassid and Sunendar (2011), the learning process consists of three stages namely the stage of information, transformation, and evaluation. What is meant by the stage of information is the process of explanation, decomposition, or guidance on the principles of the structure of knowledge, skills and attitudes. The transformation stage is the process of shifting or transferring the principles of the structure into the learners. The process of transformation is done through information.

The exotica contained in Pagatan weaving can inspire people to learn recognize the value of culture and local wisdom, thus making the source of learning for students to participate to preserve and appreciate this local culture which is not found in other areas. The principle of diversity requires cultural diversity to be maintained, for it is the culture that gives a sense of identity. Collaboration between traditional and modern culture is expected to anticipate behavioral change so that they do not feel lost competitiveness.

Weaving Pagatan as a source to build value that contains the following values:

\section{Economic Value}

Weaving is one of the activities that can be profitable economically. Weaving becomes an additional source of income for the Pagatan community in addition to their livelihoods as sailors. Pagatan weaving which was originally a traditional garment worn by people or in certain activities, now is developed in various forms of clothing. Surely this development benefits the craftsmen that their livelihood is sustained and their knowledge of weaving is increasing with their innovations.

Culture value

Pagatan woven fabric is a high-value cultural heritage. The community has been doing this weave for hundreds of years. Almost all people in various regions in Indonesia have a weaving craft. Of the many types of weaving that exist from various regions, of course, not infrequently that began to become extinct. Therefore, the Pagatan that still exists today needs to be preserved and developed as a cultural heritage.

\section{Social value}

Pagatan weaving is a cultural characteristic of Bugis immigrants in South Kalimantan. This weaving indicates that the culture that existed in most parts of Indonesia or the archipelago in the past is the result of a combination of one culture with another culture. This means that there is no culture that stands alone without any influence from other cultures. Just as acculturation of Malay culture has been going on for hundreds of years. This is characterized by cultural similarities among various Malay societies, for example in terms of language, equipment, art, clothing, and so on.

Local wisdom consists of two words, namely wisdom or policy and local or of the same place. Therefore, local wisdom is a local idea that is wise, full of wisdom, good value, embedded and followed by members of the community. Local wisdom contains goodness for human life, so this principle is descended and strongly attached to the life of local communities. Although there are differences in the character and intensity of their cultural social relationships, but over the long term they are bound in the visionary equation in creating a life of mutual dignity and prosperity. In this framework of local wisdom, inter-individual, intercommunity groups complement each other, unite and interact with maintaining prevailing social values and norms.

Cultural diversity of the area is a social potential that can form the character and image of its own culture in each region, as well as an important part for the formation of image and cultural identity of a region. In addition, diversity is an intellectual and cultural property as part of a cultural heritage that needs to be preserved. Along with the improvement of technology and cultural transformation towards modern life as well as the influence of globalization, cultural heritage and traditional values of indigenous people face the challenge to their existence. This needs to be observed because the cultural heritage and traditional values contain many local wisdom that is still highly relevant to the current conditions as well as should be preserved, adapted or even developed further.

However, in reality the noble cultural values began to dreary, fade, and the local wisdom lost its substantive meaning. Conservation efforts appear to be merely symbolic statements without meaning, appreciation and practice in everyday life. As it is known that in recent years, the culture of the community as a source of local wisdom has almost completely reduced, and appears to be just a display of formality, and often cultural institutions are generally used for commercialization and power interests. Local wisdom is a matter of identity. As a system of local knowledge, it distinguishes a local community from other local communities. The differences can be seen from the types of local wisdom that can be traced:

1. Local wisdom in relation to food: specifically related to the local environment, matched with local climates and staple foods. (For example: Sasi laut in Maluku and some other places as part of local wisdom with the aim that the food source of society can be maintained).

2. Local wisdom in relation to treatment: for prevention and treatment. (For instance: Each area has traditional medicinal plants with different properties).

3. Local wisdom in relation to the production system: Of course it deals with traditional local production systems, as part of the effort to meet the needs and management of the workforce. (For example: Subak in Bali; in Maluku there is Masohi to open agricultural land, etc.).

4. Local wisdom in relation to housing: adapted to the climate and raw materials available in the region (For instance: Banjar House, Bubungan Tinggi House, etc).

5. Local wisdom in relation to clothing: adapted to the climate and raw materials available in the region. 
6. Local wisdom in human relationships: a system of local knowledge as a result of the continuous interaction built upon these needs. (For example: Pela's relationship in Maluku also related to food, housing, production systems and so on).

\section{Educative Values of Pagatan Weaving}

The character values contained in the weaving activity are:

1. Hard work: actions that demonstrate orderly behavior and abide by various rules and regulations.

2. This can be seen from the activity of weaving that takes days or even weeks can even take a month in working on one product woven fabric Pagatan.

3. Creative: think and do something to produce new ways or results from something that has been owned.
4. In order not to lose competitiveness with other fabric products, craftsmen should always be creative to follow the development of the era do not forget its peculiarities.

5. Independent: attitudes and behaviors that are not easy depending on others in completing tasks.

6. As the weavers are required to be independent in choosing materials and creatively combined matching for the motive and style is always interesting and has exotic value.

7. Caring for the environment: attitudes and actions that always seek to prevent damage to the surrounding natural environment, and develop efforts to repair the natural damage that has occurred.

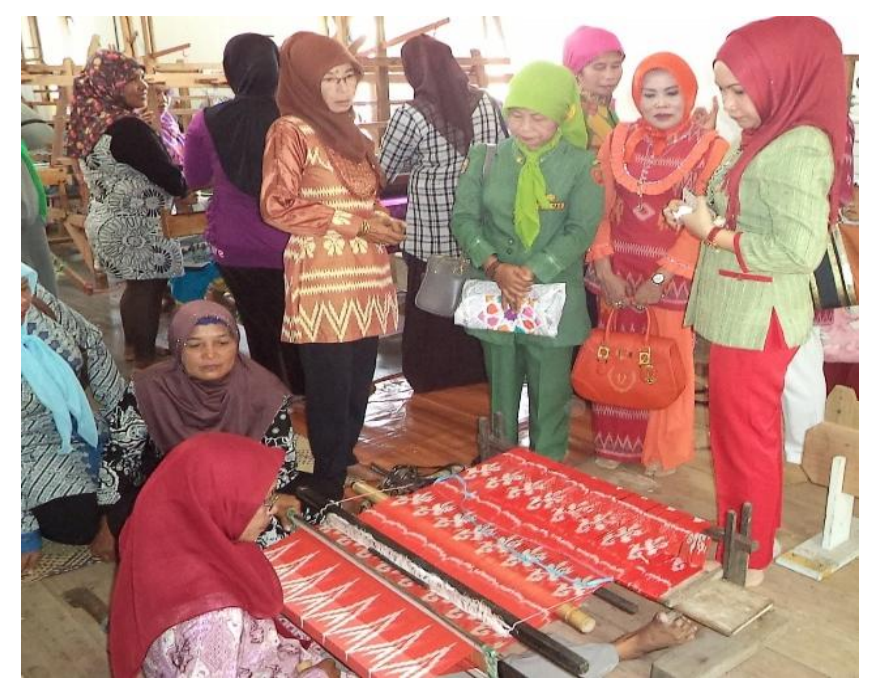

Figure 2

The Head of Dekranasda Tanah Bumbu Hj. Erwinda Mardani was Observing Participants the Training of iNcreasing Pagatan Weaving Source: http://kalsel.antaranews.com

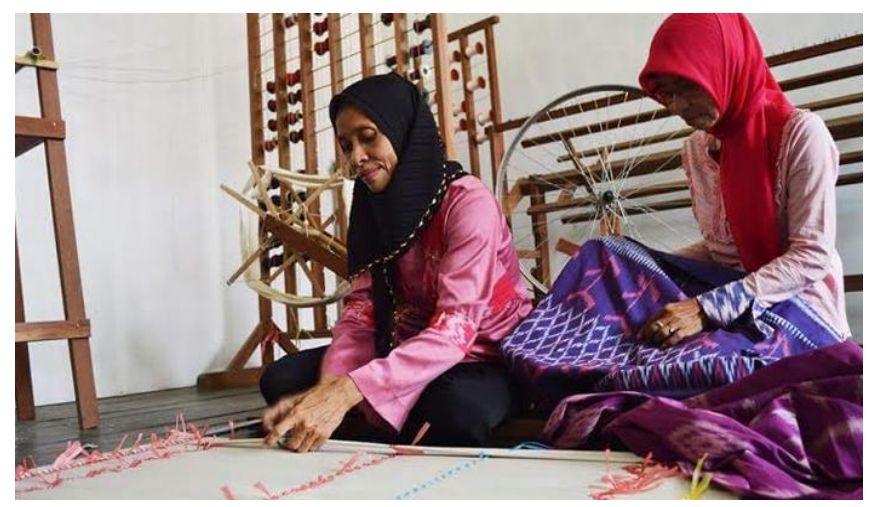

Figure 3

The Woman weave the Pagatan Weaving/Special Weaving of South Kalimantan Source: http://www.tribunnews.com

This is marked by the spirit to preserve Pagatan's weaving to always exist among the people of Kalimantan generally and the Pagatan community in particular as shown in Figure 2 and 3. Thus, the values are integrated and educative in the process of weaving Pagatan woven fabric sebayak 4 characters. The characters are: hard work, creative, independent, and care about the environment. These values are in 
accordance with the character that character education that has been proclaimed by the government for a long time. This is in line with UU no 20 year 20013 about Sisdiknas (article 3) is "for the development of the potential of learners to be human yag faithful and cautious to God Almighty, have noble character, healthy, knowledgeable, creative, independent, and become citizen which is democratic and responsible.

Pagatan weaving as a learning resource can be packaged into learning materials at the elementary to high school level by paying attention to and referring to the standard of competence and basic competencies established by the government. Basic competence and basic competence standards are derived by the government so that it becomes a wedge in planning learning in the classroom. The appropriate competency standard and basic competence standard will produce the local-oriented wisdom-oriented teaching materials.

In other words, materials sourced from local wisdom will be material that can be learned to the students without leaving the material set by the government. Packaging Pagatan weaving process can be a source of learning disesuiakn with subjects to be learned in accordance with the provisions of the curriculum in force in schools. The values contained in the Pagatan weaving process are internalized in the emperic world. For example character education that is integrated in social studies subjects. Through IPS learning with Pagatan weaving material can be referenced as a traditional economic activity. In the weaving process there are good values to be learned to the students so that students will be more aware of character learning through empiric approach.

\section{CONCLUSION AND SUGGESTION Conclusion}

It is not doubt originally woven fabric Pagatan one of Indonesia's original local cultural products are also threatened with extinction. Woven fabric typical community Pagatan Bugis tribe, subdistrict Kusan Hilir Tanah Bumbu Regency is a cultural heritage that must be preserved down and down. Weaving Pagatan as a source to build a very profitable economic value as a source of income, cultural values that need to be passed down from generation to generation and social values that characterize Bugis Pagatan people.

In this framework of local wisdom, inter-individual, inter-community groups complement each other, unite and interact with maintaining prevailing social values and norms. Local wisdom is a matter of identity. As a system of local knowledge, it distinguishes a local community from other local communities.

Pagatan weaving as a learning resource is able to be packaged into learning materials at the elementary to high school level by paying attention to and referring to the standard of competence and basic competencies established by the government. Basic competence (SK) and basic competence standards (KD) are derived by the government.in short, it becomes a wedge in planning learning in the classroom. The appropriate competency standard and basic competence standard will produce the localoriented wisdom-oriented teaching materials. In other words, materials sourced from local wisdom will be material that can be learned to the students without leaving the material set by the government.

Packaging Pagatan weaving process can be a source of learning is appropriately with subjects to be learned in accordance with the provisions of the curriculum in force in schools. The values contained in the Pagatan weaving process are internalized in the empiric world. For example, character education is integrated in social studies subjects. Through IPS subject with Pagatan weaving material can be referenced as a traditional economic activity. In the weaving process, there are good values to be learned to the students so that students will be more aware of character learning through empiric approach. Pagatan weaving is a local wisdom of South Kalimantan that can be empowered to be a source of learning in formal education. The utilization of these learning resources should be appropriate with the government regulations so that their utilization is more systemic and measurable.

\section{Suggestion}

Culture coming from outside is sometimes more desirable for now, whereas local culture is forgotten even threatened extinction, one of them is local wisdom of Pagatan Village as producer of Pagatan weaving which is not owned by other area, because need many parties that have to synergize for local wisdom remain Survive and continue to be preserved.

\section{REFERENCES}

[1] Budhi, S. 2015. Bugis Pagatan: Migration, Adaptation and Identity. IOSR Journal Of Humanities And Social Science (IOSR-JHSS), 20(5), 71-78.

[2] Creswell, W. J. 2005. Educational Research: Planning, Conducting, and Evaluating Quantitative and Qualitative Research. New Jersey: Pearson.

[3] Hermanto, \& Winarto. 2010. Ilmu Sosial Budaya Dasar. Jakarta: Bumi Aksara.

[4] Iskandarwassid, S. D. 2011. Strategi Pembelajaran Bahasa. Bandung: Remaja Rosdakarya.

[5] Kamon, Y. 1983. Over 1000 Patterns of Traditional Stripes and Lattices Design Collection. Tokyo: Graphic-sha.

[6] Manjta, W. 2008. Desain Penelitian Kualitatif Pendidikan dan Manajemen Pendidikan. Malang: Elang Mas.

[7] Mendikbud. 2005. Peraturan Pemerintah No. 19 Tahun 2005 tentang Standar Pendidikan. Jakarta: Mendikbud.

[8] Mendiknas. 2003. Undang-undang No. 20 Tahun 2003 tentang Sistem Pendidikan Nasional. Jakarta: Depdiknas.

[9] Ormrod, J. E. 2008. Psikologi Pendidikan. Jakarta: Erlangga. 